\title{
Analysis of chitinase expression in the crayfish plague fungus Aphanomyces astaci
}

\author{
M. Gunnar Andersson, Lage Cerenius* \\ Department of Comparative Physiology, Evolutionary Biology Centre, Uppsala University, Norbyvägen 18A, \\ 75236 Uppsala, Sweden
}

\begin{abstract}
Chitinase, as determined by enzymatic activity in the growth medium and by transcription of the chitinase gene AaChi1, is expressed at a high level during vegetative growth of the crayfish pathogen Aphanomyces astaci and expression is not further stimulated by chitin. Expression is not detected in zoospores and it does not increase to high levels until late during germination. Upon sporulation, chitinase expression increases to levels comparable with those seen in fast-growing mycelium. This pattern of chitinase expression is a common feature of strains representing all currently known genotypes of $A$. astaci, suggesting that it is an adaptation to the exclusively parasitic life-style of this species. In contrast, other Aphanomyces spp. including the saprophytes, A. laevis and A. stellatus, produce significant amounts of chitinase only in the presence of chitin. The pattern of chitinase expression is one of very few qualitative physiological characteristics known which can distinguish $A$. astaci from other parasitic and saprophytic species and may thus be of practical use for identification.
\end{abstract}

KEY WORDS: Chitinase $\cdot$ Aphanomyces astaci $\cdot$ Parasite $\cdot$ Oomycete $\cdot$ Crayfish plague Resale or republication not permitted without written consent of the publisher

\section{INTRODUCTION}

The oomycete Aphanomyces astaci is a pathogen of freshwater crayfish. It is a highly specialised parasite that cannot survive in nature without its host (Scott 1961, Unestam 1972). In some species of crayfish, including all native European species, challenge with A. astaci will result in death from acute crayfish plague, while in others the mould grows as a mostly benign infection in the cuticle (Unestam 1972). Although $A$. astaci is easily grown in axenic culture, it seems to be unable to compete with other microorganisms, including bacteria and the ubiquitous saprophyte A. laevis, outside its crayfish host, and it does not persist in lakes that have been depleted of crayfish (Cerenius \& Söderhäll 1992).

The parasite first appeared in Europe around 1860 and was introduced in Sweden in the early 20th century. Isolates from this time all belong to the same genotype, referred to as Genotype 1 (Huang et al. 1994). With the introduction of crayfish stocks from

*Corresponding author. E-mail: lage.cerenius@ebc.uu.se northern America in the 1970s and onward, new genotypes have been introduced. Strains belonging to Genotypes 2 and 3 originate from signal crayfish Pacifastacus leniusculus imported to Sweden from northern USA (Lake Tahoe) and Canada (Pitt Lake) respectively (Huang et al. 1994). A single isolate, belonging to Genotype 4, originates from Louisiana crayfish Procambarus clarkii (Diéguez-Uribeondo et al. 1995) imported into Spain.

Aphanomyces astaci propagates by releasing asexual zoospores that have the ability to swim towards a potential host attracted by chemotaxis. Upon contact with the host, the zoospore encysts and a penetration peg emerges from the cyst. The first line of defence that a mould encounters during the infection is the cuticle of the crayfish, consisting of lipids, proteins and chitin. The cuticle is penetrated by a combination of mechanical force and enzymatic activities (Nyhlén \& Unestam 1975).

Fungal and oomycete pathogens on insects and crustaceans secrete several types of lytic enzymes, including lipases, proteases and chitinases (Unestam 1966, Söderhäll \& Unestam 1975, Persson et al. 1984, Samuels et al. 1989, Clarkson \& Charnley 1996, Dieguez- 
Uribeondo \& Cerenius 1998, Vilcinscas \& Götz 1999). Although proteases are often considered to be most important, chitinases have been associated with virulence in some fungi pathogenic to insects, e.g. Metarhizium anisopliae (St Leger et al. 1991) Beauveria bassiana (Havukkala et al. 1993) and Nomuraea rileyi (El-Sayed et al. 1989). The insect pathogenic fungi that have been studied express their major chitinases in response to chitin oligomers and available nutrients ( $\mathrm{St}$ Leger et al. 1996a, Escott et al. 1998, Schickler et al. 1998). In contrast to this, A. astaci has been reported to produce high chitinase activity regardless of the presence of chitin (Unestam 1966), possibly as an adaptation to its apparently exclusively parasitic lifestyle.

Since this is one of very few potential virulence factors that have been suggested for this parasite, we were interested to know whether constitutive chitinase production is a conserved feature of all Aphanomyces astaci genotypes, as opposed to other Aphanomyces spp., and to characterise the expression pattern of chitinase in A. astaci.

\section{MATERIALS AND METHODS}

Growth of fungi. Aphanomyces astaci strains Hö, G1, L1, Kv, Pc were taken from the stock cultures of the Department of Comparative Physiology, Uppsala, Sweden. A. laevis CBS 107-52 and CBS 465-64 and A. stellatus CBS 568-67 were taken from Centralbureau vor Schimmelcultures, Baarns, the Netherlands. A. invadans strains p197 and T99G2 were gifts from Jim Lilley, Institute of Aquaculture, University of Stirling, UK. The strains An and Se are non-pathogenic Aphanomyces spp. isolated from dead crayfish. The fungi were grown in peptone-glucose medium (PG1) as described by Söderhäll et al. (1978). For chitinase expression experiments, mycelia were grown in dropcultures of $0.5 \mathrm{ml}$ liquid medium, inoculated with approximately 1 to $2 \mathrm{~mm}^{2}$ of mycelium. After $3 \mathrm{~d}$, when the mycelium had reached the stationary phase, the medium was replaced with $1 \mathrm{ml}$ of fresh PG1 or PG1 modified as specified for each experiment. At the end of an experiment, mycelia were quick-frozen in liquid nitrogen and stored at $-80^{\circ} \mathrm{C}$. Sporulation was induced by washing $3 \mathrm{~d}$ old drop cultures with lake-water as described in Cerenius \& Söderhäll (1985). Cysts were produced from zoospores by agitation as described in Diéguez-Uribeondo et al. (1994) and immediately collected by centrifugation at $2700 \times \mathrm{g}$ for $10 \mathrm{~min}$ at $10^{\circ} \mathrm{C}$. The spore pellet was frozen in liquid nitrogen and stored at $-80^{\circ} \mathrm{C}$. To obtain a synchronous population of germinating cysts, approximately $10 \mu \mathrm{l}$ of crayfish serum was evenly spread on a $9 \mathrm{~cm}$ plastic petri-dish. After drying the coated plate, swimming zoospores were allowed to spontaneously encyst and germinate. At different timepoints the water was removed and the germlings were washed off the plate with $0.75 \mathrm{ml}$ Trizol (Life Technologies) and frozen at $-80^{\circ} \mathrm{C}$.

Chitinase activity measurements. Chitinase activity in the growth medium was measured with 4-methylumbelliferyl- $\beta-\mathrm{D}-\mathrm{N}, \mathrm{N}^{\prime}, \mathrm{N}^{\prime \prime}$-triacetylchitotioside (4-MUchitotrioside) (Sigma), which is a substrate for both endo- and exochitinases (Tronsmo \& Harman 1993). The assays were conducted in a 96-well microtiter plate and a typical $100 \mu \mathrm{l}$ reaction contained $180 \mu \mathrm{M}$ substrate, $5 \mathrm{mM}$ sodium-phosphate buffer, $\mathrm{pH} 6.8$ and $75 \mu$ l test solution. The substrate, buffer and test solution were mixed by pipetting and incubated at $20^{\circ} \mathrm{C}$ for $1 \mathrm{~min}$ to $2 \mathrm{~h}$. At different timepoints the intensity of the fluorescence was monitored on a UV table and compared with that of serial dilutions of the product, 4-methylumbelliferone. This method can detect product concentrations ranging from 0.5 to $50 \mu \mathrm{M}$. If no fluorescence was detected after $2 \mathrm{~h}$ incubation, the sample was counted as negative. Enzyme activity was calculated as nmol product formed per min per mg dry mycelium.

In some experiments chitinase activity was measured against colloidal chitin as outlined in Unestam (1966).

Cloning of the chitinase gene AaChi1. Genomic DNA from Aphanomyces astaci was isolated with the Puregene kit (Gentra), followed by phenol-chloroform extraction (Sambrook et al. 1989). No amino acid or DNA sequences have so far been reported from chitinases from any oomycetes. We designed PCR primers based on sequence motifs that are conserved between various acidic and basic chitinases from bacteria, plants and fungi. A fragment of the chitinase encoding gene AaChi1 was successfully amplified using PCR primers corresponding to the catalytic site and the substrate binding site 2 (see Fig. 1). PCR was run with $50 \mathrm{mM}$ dNTP, $50 \mathrm{mM}$ Tris/HCl pH 8.5, $16 \mathrm{mM}$ $\left(\mathrm{NH}_{4}\right)_{2} \mathrm{SO}_{4}, 50 \mathrm{mM} \mathrm{KCl}, 7 \mathrm{mM} \mathrm{MgCl}_{2}, 2 \mu \mathrm{M}$ each of the degenerate primers (GAY GGI WTH GAY WTH GAY TGG) and (CCI GCR WAR TCR TAI GCC ATN ARR TT) at $95^{\circ} \mathrm{C}$ for $5 \mathrm{~min}$, followed by 35 cycles at $95^{\circ} \mathrm{C}$ for $30 \mathrm{~s}, 55^{\circ} \mathrm{C}$ for $1 \mathrm{~min}, 72^{\circ} \mathrm{C}$ for $1 \mathrm{~min}$, and a $30 \mathrm{~min}$ extension at $72^{\circ} \mathrm{C}$. The PCR product was ligated into pBluescript (Stratagene) by T-vector cloning (Marchuk et al. 1991) and amplified in XL1-blue MRF' cells (Stratagene).

The cloned fragment was reamplified by PCR with the same primers, random-labelled with $\left[\alpha^{32} \mathrm{P}\right]$ deoxyCTP (Amersham) using the Megaprime labelling kit (Amersham), purified on a Nick column (Pharmacia) and eluted in $10 \mathrm{mM}$ Tris/HCl, $1 \mathrm{mM}$ EDTA, pH 7.5. This probe, named Chi1, was used to screen a lambda FIX II genomic library from Aphanomyces astaci, strain Hö, described in Bangyeekhun et al. (2001). 


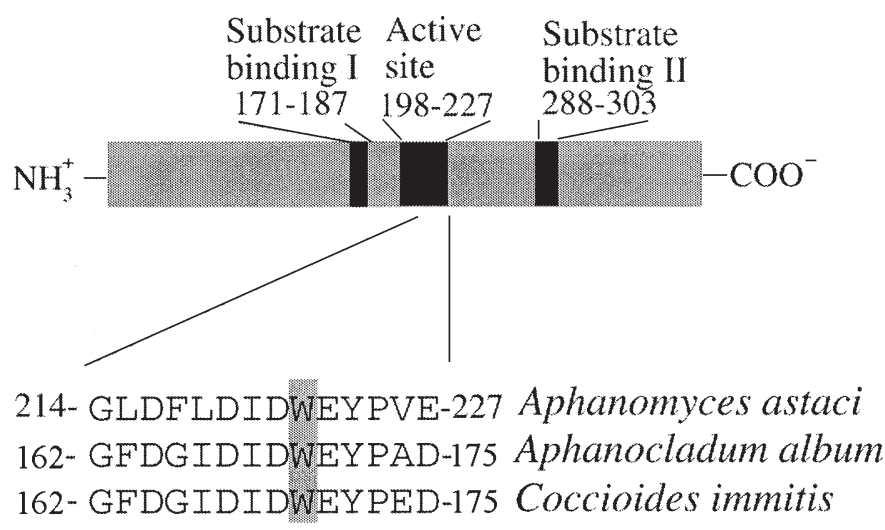

Fig. 1. Schematic view of the putative chitinase AaChi1. Upper section: positions of substrate binding and catalytic regions in the predicted chitinase AaChil according to definitions in Shakarian \& Dwyer (1998). Lower section: alignment of the active site of AaChi1 with other Class I chitinases. The numbering indicates amino acid positions according to accession numbers AJ416354 (Aphanomyces astaci), X64104 (Aphanocladum album), and P54196 (Coccioides immitis)
Lambda DNA was prepared using the Wizard lambda DNA preparation kit (Promega). DNA from the different clones were sequenced with an ABI-Prism 377 DNA sequencer (Perkin-Elmer), using gene specific primers, which have been constructed according to the sequence information obtained from the cloned PCR product and the genomic clone. Sequences were analysed using MacVector 4.1.4 (Eastman Kodak) and assembled using AssemblyLIGN 1.0.2 (International Biotechnologies). Related proteins were identified using BLAST 2.0 (Altschul et al. 1997) and the deduced amino acid sequence was aligned to other chitinases, using ClustalW 1.7 multiple sequence alignment (Thompson et al. 1994).

Northern and Southern blots. Frozen mycelia were ground in liquid nitrogen and total RNA was isolated using GenElute mammalian total RNA isolation kit (Sigma) according to the manufacturer's instructions. Frozen cysts were thawed and resuspended in Trizol. The resuspended cysts were studied using an inverted microscope to confirm the synchrony of encystment or germination. The cysts were disrupted by vortexing with 425 to $600 \mu \mathrm{m}$ glass beads (Sigma) in the Trizol solution. RNA extraction proceeded according to the manufacturer's instruction. Northern blot analysis was performed with $10 \mu \mathrm{g}$ of total RNA according to the protocol of Sambrook et al. (1989). After denaturation the samples were mixed with $0.5 \mu$ l ethidium bromide $\left(1 \mathrm{mg} \mathrm{ml}^{-1}\right)$ and analysed on a $1 \%$ agarose gel (20 mM MOPS, $8 \mathrm{mM} \mathrm{NaAc}, 5 \mathrm{mM}$ EDTA, $2 \%$ formaldehyde, $\mathrm{pH}$ 6), together with a 0.28 to $6.58 \mathrm{~kb}$ size marker (Promega). The gel was capillary blotted to Hybond$\mathrm{N}+$ membrane (Amersham). After blotting RNA was fixed by UV-crosslinking in a Stratalinker 1800 (Stratagene).

For Southern blot analysis, aliquots of genomic DNA were cleaved with the restriction enzymes EcoR1, Sal1 and Kpn1 (Amersham) respectively. The fragments were separated on a $0.8 \%$ agarose gel $(40 \mathrm{mM}$ Tris/borate, 1 mM EDTA, pH 7) and blotted to Hybond $\mathrm{N}+$ transfer membrane (Amersham) according to the manufacturer's instructions. A second probe Chi1-14c was constructed by PCR amplification of a fragment of the genomic clone AaChi1-14c using primers ChiPCR1forward (GGTTCAAGCAAAAGCA) (Positions 739 to 754 in AJ416354) and ChiPCR2reverse (TGGTGGTCCGTGTATT) (Positions 1159 to 1174 in AJ416354). Both probes were labelled as described above and hybridised to the membranes according to the manufacturer's instructions. The membranes were washed twice for $15 \mathrm{~min}$ each in $2 \times \mathrm{SSC}, 0.1 \% \mathrm{SDS}$, and once for $15 \mathrm{~min}$ in $1 \times \mathrm{SSC}, 0.1 \% \mathrm{SDS}$. The membranes were exposed to a BAS 1500 II image plate (Fuji). After scanning, the images were analysed and signal intensity-quantified, using Image gauge 3.46 (Fuji Photo Film). Before printing, brightness and contrast was adjusted with Photoshop 4.0 (Adobe systems).

RT-PCR. Total RNA was treated with DNase 1 (Amersham Pharmacia Biotech), purified by Qiaquick PCR-Purification kit (Qiagen) and eluted in DEPCtreated water. CDNA for RT-PCR was synthesised from $0.5 \mu \mathrm{g}$ of total RNA using primer $\mathrm{T}_{30} \mathrm{~V}$ and Superscript II (Gibco) reverse transcriptase according to the instructions of the manufacturer. Negative controls, without reverse transcriptase, were made for all reactions. PCR was performed in $10 \mu \mathrm{l}$ reactions at the following conditions: $1 \mu \mathrm{l}$ cDNA (corresponding to $25 \mathrm{ng}$ total RNA), $1 \times$ PCR buffer (Amersham), $200 \mu \mathrm{M}$ each $\mathrm{dNTP}, 0.2 \mu \mathrm{M}$ of each primer, 0.5 units Taq polymerase (Amersham), 0.5 units Antitaq antibodies (Clontech). For chitinase the PCR was performed with primers AaChiSeq1reverse (GCAGATGGCGGTAAAGT) (positions 1103 to 1119 in AJ416354) and ChiPCR1forward (see above) with an annealing temperature of $47^{\circ} \mathrm{C}$. For actin we used the primers (TTACTCGTTCACCACCAC) and (CCGCCCGACAACACAATG) with an annealing temperature of $53^{\circ} \mathrm{C}$. The actin specific primers correspond to Positions 594 to 702 and 890 to 908, respectively, in X59936. The cycling conditions were $95^{\circ} \mathrm{C}$ for $5 \mathrm{~min}, 30$ to 35 cycles of 
$\left(95^{\circ} \mathrm{C}\right.$ for $30 \mathrm{~s}, 47 / 53^{\circ} \mathrm{C}$ for $30 \mathrm{~s}$ for chitinase/actin, $72^{\circ} \mathrm{C}$ for $30 \mathrm{~s}$ ), and a final elongation step at $72^{\circ} \mathrm{C}$ for 7 min. The PCR product was separated on a $1.5 \%$ agarose gel containing ethidium bromide (Sambrook et al. 1989), and the fragments were visualised by UV-light.

\section{RESULTS}

\section{High chitinase activity is produced by all Aphano- myces astaci genotypes in the absence of chitin}

Chitinase expression has been suggested as a virulence factor for Aphanomyces astaci and thus we were interested to know whether expression of chitinase in the absence of chitin, as reported by Unestam (1966), is a common feature of $A$. astaci genotypes. Strains representing each of the 4 known genotypes of $A$. astaci as well as some of other parasitic and saprophytic Aphanomyces spp. were analysed with respect to chitinase secretion into the medium. The strains were grown for $3 \mathrm{~d}$ and transferred to fresh PG1, or PG1 where glucose was replaced by colloidal chitin, for $9 \mathrm{~h}$. Chitinase activity in the medium was assayed by a microtiter-plate assay. All strains of A. astaci secreted high levels of chitinase both in PG1 and chitin medium (Table 1). Neither the fish pathogen $A$. invadans, the non-pathogenic Aphanomyces sp. from crayfish, nor the saprophytes $A$. stellatus and $A$. laevis produced significant levels of chitinase when grown in a chitinfree medium. Some activity was, however, detected in the supernatants from dense cultures of A. laevis, but this activity was at least 3 to 4 orders of magnitude lower than that seen with $A$. astaci. When grown in a medium containing chitin, activity was strongly induced in A. stellatus, A. laevis and the nonpathogenic Aphanomyces sp., while A. invadans failed to grow (Table 1). Culture supernatants that show activity against 4-MU-chitotriose can also, as shown earlier by Unestam (1966), completely degrade colloidal chitin into soluble material, confirming endochitinase activity (data not shown).

\section{Chitinase AaChi1 is transcribed in growing mycelia of Aphanomyces astaci}

With chitinase being a potential virulence factor of Aphanomyces astaci, we were interested in studying its expression in more detail. To obtain a probe for studying the expression of chitinase at the transcriptional level we used PCR with degenerate primers to amplify a 264 nucleotide fragment, denoted Chi1, which was used to screen the A. astaci genomic library. One of the clones from the screen, AaChi1-14c (EMBL AJ416354), was sequenced and the predicted protein AaChi1 showed the highest similarity to imperfect fungus Aphanocladum album chitinase1 (EC 3.2.1.14). Alignments with other chitinases identified a conserved active site (Shakarian \& Dwyer 1998), with substrate-binding and catalytic sites (Huang et al. 2000) (Fig. 1). The genomic clone was subsequently used to produce probes for Northern and Southern blots. On a Southern blot, the probe Chi1-14C, which does not contain the restriction sites (EcoRI, KpnI and SalI),

Table 1. Extracellular chitinase activities in different Aphanomyces strains. Chitinase activity expressed as nmol released 4-methylumbelliferone $\mathrm{min}^{-1} \mathrm{mg}^{-1}$ dry mycelium. na: failed to grow in this medium; nd: not detected

\begin{tabular}{|c|c|c|c|c|c|c|}
\hline Strain & Species & Country & Origin & Year & $\begin{array}{l}\text { Chitinase } \\
\text { - chitin }\end{array}$ & $\begin{array}{l}\text { Chitinase } \\
\text { + chitin }\end{array}$ \\
\hline L1 & Aphanomyces astaci type 1 & Sweden & Astacus astacus & 1962 & $>50$ & $>50$ \\
\hline G1 & Aphanomyces astaci type 1 & Sweden & Astacus astacus & 1962 & $>50$ & $>50$ \\
\hline Нӧ & Aphanomyces astaci type 2 & Sweden & Astacus astacus & 1974 & $>50$ & $>50$ \\
\hline $\mathrm{Kv}$ & Aphanomyces astaci type 3 & Sweden & Pacifastacus leniusculus & 1978 & $>50$ & $>50$ \\
\hline $\mathrm{PC}$ & Aphanomyces astaci type 4 & Spain & Procambarus clarkii & 1988 & $>50$ & $>50$ \\
\hline An & Aphanomyces sp. ${ }^{\mathrm{a}}$ & Spain & Pacifastacus leniusculus & 1998 & nd & $>10$ \\
\hline $\mathrm{Se}$ & Aphanomyces sp. ${ }^{\mathrm{a}}$ & Spain & Pacifastacus leniusculus & 2000 & nd & $>10$ \\
\hline $107-52$ & Aphanomyces laevis ${ }^{\mathrm{b}}$ & - & - & - & $<0.05$ & $>10$ \\
\hline $465-64$ & Aphanomyces laevis ${ }^{\mathrm{b}}$ & Germany & Soil & - & $<0.05$ & $>10$ \\
\hline $568-67$ & Aphanomyces stellatus ${ }^{\mathrm{b}}$ & - & - & - & nd & $>10$ \\
\hline P197 & Aphanomyces invadans ${ }^{\mathrm{C}}$ & Thailand & Channa striata & 1995 & nd & na \\
\hline T99G2 & Aphanomyces invadans ${ }^{\mathrm{c}}$ & Thailand & Osphronemuc goramy & 1999 & nd & na \\
\hline \multicolumn{7}{|c|}{${ }^{a}$ Low virulence against crayfish } \\
\hline \multicolumn{7}{|c|}{${ }^{\mathrm{b}}$ Centralbureau voor Schimmelcultures, Baarns, The Netherlands } \\
\hline
\end{tabular}


hybridised to approximately 7 to 8 fragments with each of these restriction enzymes (Fig. 2). With the restriction enzymes ECoR1 and Sal1, 2 fragments of stronger intensity are produced, which may represent the nearest homologues. DNA from other A. astaci strains produced similar patterns, whilst the DNA from the other Aphanomyces spp. produced different patterns but approximately the same number of fragments, all with an intensity similar to the weaker bands from $A$. astaci (results not shown). Since oomycetes are diploid, this indicates that there are at least 3 to 4 related genes present in the genome of all the strains used in our experiments.

On Northern blots a single $1.5 \mathrm{~kb}$ band was detected with the probe Chi1-14C in strains from each of the 4 Aphanomyces astaci genotypes when grown in PG1 medium without chitin (data not shown). No signal was detected in the other Aphanomyces spp., irrespective of the presence of chitin, probably as a result of using a heterologous probe, in combination with lower expression levels. To study the expression of AaChi1 in different phases of growth, the medium from $3 \mathrm{~d}$ old mycelium of strain Hö was replaced with fresh PG1 or PG1 where glucose was replaced by colloidal chitin. Mycelia were collected at different timepoints from 0 to $40 \mathrm{~h}$ and analysed for dry weight and AaChi1 expression (Fig. 3). In growing mycelia, collected between about 9 and $24 \mathrm{~h}$ after the addition of fresh medium, expression was found to be high, while it was low in the lag phase and in the stationary phase.

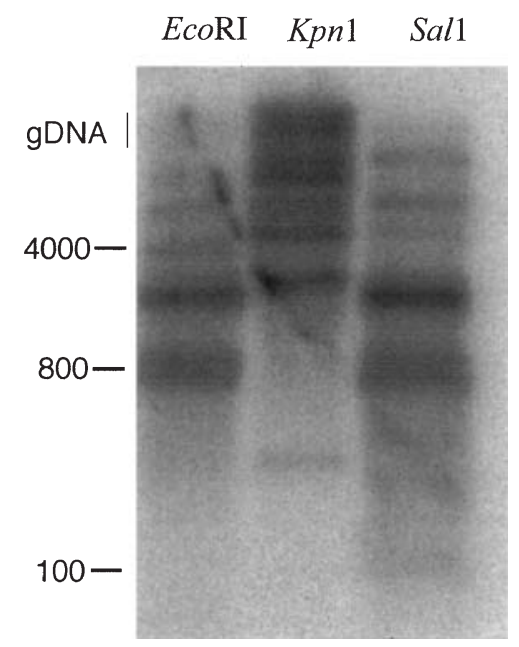

Fig. 2. Southern blot with genomic DNA from Aphanomyces astaci, strain Hö, cleaved with EcoR1, Kpn1 and Sal1. Probed with Chi1-14c. Size of molecular size standards as number of basepairs shown to the left. Vertical line indicates the position of undigested genomic DNA ('gDNA') present in lane Kpn1. Little or no undigested DNA was seen with the other enzymes

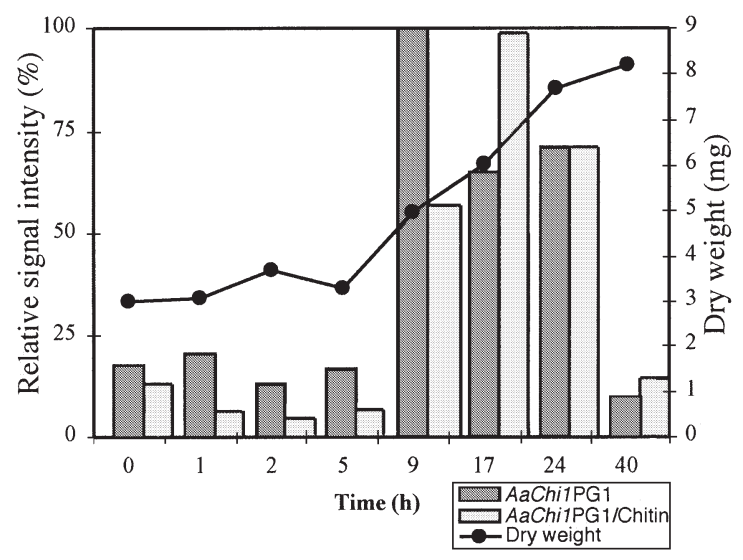

Fig. 3. Increase in AaChi1 transcript levels during growth phase. Bars: relative transcript levels quantified from Northern blots of Aphanomyces astaci, strain Hö, grown for 0 to $40 \mathrm{~h}$ after transfer to fresh PG1 or PG1 where glucose was replaced with $0.6 \%$ colloidal chitin. The blots were hybridised with ${ }^{32} \mathrm{P}$-labelled Chi1-14c probe (arbitrary units). Line: dry weight of mycelium (mg), average of 3 drop cultures. No difference is seen in the growth rate of the mycelium when glucose in the medium is replaced by chitin. A 3-fold or higher increase in AaCHi1 transcript levels in growing mycelia as compared to mycelia in lag or stationary phase has been observed in at least 3 independent experiments

\section{AaChi1 is negatively affected by GlcNac presence}

Induction by chitin and repression by glucose and the end-product, N-acetylglucoseamine (GlcNac), are common features of chitinase regulation in fungi, and we were interested to know how these compounds affect the expression of AaChi1. The PG1 medium from $3 \mathrm{~d}$ old drop cultures was replaced with either PG1 with $1 \%$ GlcNac, PG1 without glucose, PG1, or PG1 where glucose is replaced with colloidal chitin ( 0.6 or $0.06 \mathrm{mg} \mathrm{ml}^{-1}$ ) and the mycelia were incubated for an additional period to ensure that the mycelia had entered the growth phase. The results from Northern blots showed that $1 \%$ GlcNac strongly inhibits expression of the AaChi1 transcript at 9 h (Fig. 4). In contrast, the results did not indicate stimulation by chitin or repression by glucose (Fig. 4). AaChi1 expression in media containing glucose or chitin has been compared at different phases of growth but significant differences between the 2 media have not been found at any timepoint (Fig. 3) and no difference in growth rate has been noticed between mycelia grown on glucose or chitin.

We also tested the effect of GlcNac on the secretion of chitinase into the growth medium. When the fungus was grown for $3 \mathrm{~d}$ in media containing $0.5 \%$ GlcNac, chitinase activity was partly inhibited relative to the 


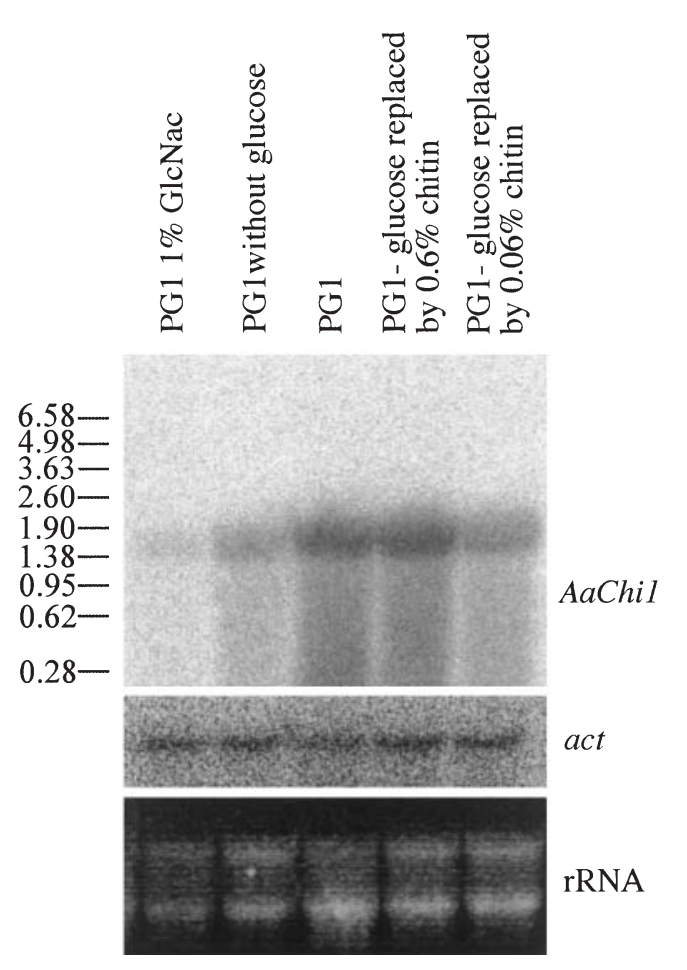

Fig. 4. Effect of GlcNac, glucose and chitin on expression of AaChi1. Northern blot of total RNA hybridised with Chi1-14c (upper lane) and rehybridised with actin (middle lane). Ribosomal RNA, stained with EtBr (lower lane). Mycelia of strain Hö were grown for $3 \mathrm{~d}$ in PG1, after which time medium was replaced with fresh test medium and grown for an additional $9 \mathrm{~h}$. PGI:peptone-glucose medium. All media contain peptone, salts and phosphate buffer. The results are representative of 3 independent experiments

control, at $1 \%$ GlcNac no activity was detected, and the activity could not be restored by separating the secreted protein from GlcNac by dialysis. In a control experiment, GlcNac was added to the collected supernatant, containing active chitinase. In this case enzymatic activity was also inhibited by $1 \%$ GlcNac, but activity was restored after dialysis (data not shown). These results show that $1 \%$ GlcNac both inhibits the activity of the enzyme and its production.

\section{Expression of chitinase during asexual life cycle}

We also studied the expression of chitinase in the different stages of the infection cycle. Northern blots did not detect any AaChi1 transcript in cysts or young germlings incubated for $4 \mathrm{~h}$ in PG1 (data not shown). In a more detailed study by RT-PCR, the transcript was detected $2.5 \mathrm{~h}$ after induction of germination by crayfish serum but the amount of the transcript (per $\mu \mathrm{g}$ of total RNA) increased only slowly (Fig. 5), and had not

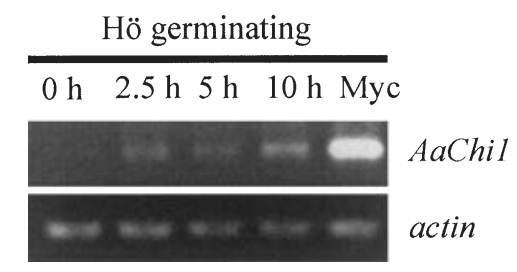

Fig. 5. Time-dependent induction of AaChi1 transcript in germinating Aphanomyces astaci (strain Hö) cysts, following serum induced germination. RT-PCR with primers against AaChi1 (35 cycles) and actin (30 cycles). RNA from vegetative mycelium is used as control. No PCR product was seen in the corresponding controls without reverse transcriptase. Similar

results have been obtained in 2 independent experiments

reached high levels until $10 \mathrm{~h}$ after encystment. Actin mRNA, which was used as a control, could be detected at all timepoints. In concordance with these results, no chitinase activity was detected in supernatants from recently formed cysts or from germlings younger than about $6 \mathrm{~h}$, and activity did not reach significant levels until after $10 \mathrm{~h}$ (results not shown). Also no detectable chitinase activity was found in homogenates from cysts or zoospores.

\section{Expression of chitinase in sporulating Aphanomyces astaci}

In the last stage of the infection, asexual zoospores are released from hyphae emerging from the dying crayfish. To simulate this, sporulation was induced by washing $3 \mathrm{~d}$ old mycelium with lake water. Results from several experiments have shown that AaChi1 transcript levels immediately are highly variable after washing, probably reflecting the growth status of the mycelia, but drop to low levels within approximately $15 \mathrm{~min}$. During the first hours after washing, AaChi1 expression is low, typically followed by an increase (Fig. 6a) starting at about $4 \mathrm{~h}$ and eventually reaching levels comparable to those seen in the fast-growing mycelium. This increase of AaChi1 transcript is accompanied by accumulation of chitinase activity in the surrounding water (Fig. 6b). We also tested the expression of the proteinase gene AaSP2 (Bangyeekhun et al. 2001) during sporulation, and we found that expression of this transcript decreased and was almost undetectable at $7.5 \mathrm{~h}$. At the same time the control transcript, actin, was expressed at an approximately constant level.

To test whether the production of chitinase by sporulating mycelia is a general feature of Aphanomyces astaci, we grew and sporulated mycelia of the 4 A. astaci strains as well as the other Aphanomyces spp. as described above. Using the microtiter plate assay, chitinase activity was detected in the water 
a $0 \mathrm{~h} \quad 2.5 \mathrm{~h} \quad 5 \mathrm{~h} \quad 7.5 \mathrm{~h}$

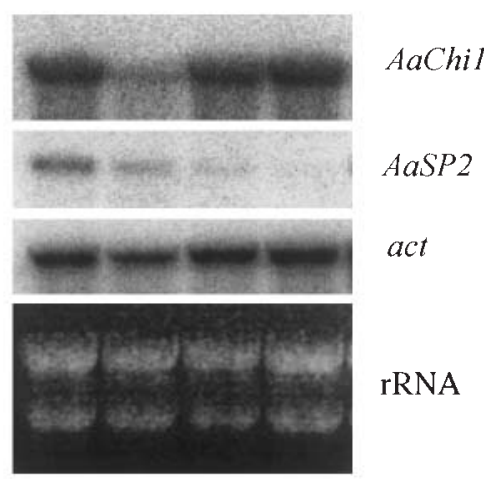

b $\quad 0 \mathrm{~h} \quad 2 \mathrm{~h} \quad 4 \mathrm{~h} \quad 6 \mathrm{~h} \quad 8 \mathrm{~h}$

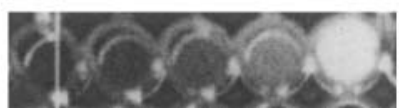

Fig. 6. (a) Expression of AaChi1 in Aphanomyces astaci, strain Hö, upon sporulation. Northern blot of total RNA from mycelia collected $0,2.5,5$ and $7.5 \mathrm{~h}$ after washing with lake water, hybridised with Chi1-14c (upper lane), a probe for the trypsin AaSP2 (middle lane), and rehybridised with actin (lower lane). Ribosomal RNA stained with EtBr. Results are representative of 4 independent experiments. (b) Representative example showing accumulation of chitinase activity in supernatants collected at 0 to $8 \mathrm{~h}$ after inducing sporulation by washing mycelia with lakewater. Fluorescent product released from 4 -MU-chitotrioside after $10 \mathrm{~min}$ incubation at $20^{\circ} \mathrm{C}$. The fluorescence corresponds to an accumulated chitinase activity of $<0.2 \mathrm{mmol} \mathrm{min}^{-1} \mathrm{mg}^{-1}$ at $4 \mathrm{~h}$, ca. $0.5 \mathrm{mmol}$ $\mathrm{min}^{-1} \mathrm{mg}^{-1}$ at $6 \mathrm{~h}$ and ca. $2 \mathrm{mmol} \mathrm{min}^{-1} \mathrm{mg}^{-1}$ at $8 \mathrm{~h}$, where $\mathrm{mg}$ refers to the dry weight of the mycelium

from the $4 \mathrm{~A}$. astaci strains but not from any of the other species.

Apparently no AaChi1 mRNA or protein is produced for storage in the zoospores and thus we suspected that the AaChi1 transcript was produced in hyphae that were still in an early stage of sporulation, or possibly as a direct result of the starvation. Unlike in Achlya klebsiana, sporulation in Aphanomyces cannot be inhibited by addition of defined compounds such as amino acids (results not shown) and in order to separate starvation and sporulation, we studied the expression of chitinase in A. astaci strain G1 (Unestam 1965). This strain, initially isolated as a fully virulent type 1 strain, has over time lost its ability to sporulate and does not show any sign of spore formation. In G1, AaChi1 was detected on Northern blots both from growing mycelium and from mycelium washed with lake water, at levels similar to or higher than in Hö (data not shown) and activity measurements showed even higher activities in G1 after washing with lake water compared to sporulating Hö, demonstrating that increased AaChi1 production can take place also without spore formation.

\section{DISCUSSION}

\section{Chitinase production in the absence of chitin is characteristic of Aphanomyces astaci}

Our results show that the pattern of chitinase expression in Aphanomyces astaci is different from that of other aquatic Aphanomyces, making it one of very few potential virulence factors identified for this organism. Previous work has shown that the parasite can be recognised by the host immune system and does not seem to produce specific toxins. This has led to the hypothesis that the success of this parasite is largely due to an optimisation of more general features, such as the mixture of secreted enzymes. Unestam (1966) reported that $A$. astaci secreted enzymes with a high activity against colloidal chitin when growing in a chitin-free medium, in contrast to the saprophyte A. laevis in which the activity was induced by chitin. Recently Bangyeekhun et al. (2001) showed that expression of the transcript AaSP2, encoding a trypsin, is strongly stimulated upon growth in crayfish serum, implying a role in pathogenesis.

In this work we have compared strains representing Aphanomyces astaci Genotype 1 (G1 and L1), Genotype 2 (strain Hö), Genotype 3 (Kv) and Genotype 4 (Pc). The results show that chitinase production in the absence of chitin is a characteristic feature of all studied A. astaci genotypes which is not shared by other aquatic Aphanomyces, and that this feature has been conserved over a long time. It also confirms, with a new assay, the results of Unestam (1966) showing that chitinase activity produced by $A$. astaci when grown in PG1 was equal to or higher than that produced by A. laevis, a saprophyte of chitinous material (Scott 1961), when the latter is grown in a medium containing chitin. Apparently A. astaci invests a lot of energy in the production of chitinolytic enzymes, suggesting that they play an important role for the success of the parasite.

\section{AaChi1 expression reflects parasitic life-style}

We have studied the expression pattern of the transcript AaChi1, encoding a putative chitinase, and in all experiments we have found a perfect correlation between the expression of this transcript and the secretion of chitinase into the medium, and thus it seems likely that it either encodes a major chitinase of Aphanomyces astaci or at least one which is co-regulated with those AaChi1, which is the first chitinase to be cloned from an oomycete, belongs to the conserved Bacillus class of chitinases, which is present in both prokaryotes and eukaryotes, and the putative enzyme contains conserved substrate-binding and cata- 
lytic sites. The presence of several related chitinases, as indicated by the Southern blot, is a common feature of chitinolytic systems in true fungi (St Leger et al. 1993, Hearn et al. 1998)

Chitinase production has been studied in several models with insect pathogenic fungi and in many of these systems a constitutive chitinase is produced at a low level while the major chitinases are induced in response to chitin degradation products. In contrast, our results indicate that Aphanomyces astaci expresses its major chitinases at high levels in the growing mycelia, without further stimulation by chitin. In the lag and stationary phases AaChi1 is expressed at a much lower level. Like most fungal systems studied, chitinase production in A. astaci is repressed by high concentrations of GlcNac, which is the end product of chitinase degradation and the repression also results in lower AaChi1 levels.

Taken together, the expression pattern of AaChi1 appears to be adapted to the parasitic life-style of Aphanomyces astaci. The observed slow increase in chitinase mRNA and enzymatic activity upon germination correlates with the apparent induction of enzymes active against colloidal chitin about 12 to $18 \mathrm{~h}$ after germination reported by Söderhäll et al. (1978). Whatever the mechanism of regulation, the parasite produces only very low levels of chitinase during the early stages of germination, which is reasonable since microscopical observation has shown that the parasite will not reach the chitinous part of the cuticle during the first $24 \mathrm{~h}$ of infection (Söderhäll et al. 1978). Once the parasite has penetrated the lipid-containing outer layers, it will penetrate the chitinous layers of the cuticle where hyphae preferentially grow along the chitin fibrils (Nyhlén \& Unestam 1980).

The chitin in the cuticle is embedded by protein and phenolic compounds, which may make it less accessible for enzymatic degradation, and it is thus possible that chitin-independent expression of large amounts of chitinase may contribute to a more rapid colonisation of the host than if the parasite relied on inducible chitinases. Aphanomyces astaci does not seem to live outside its host, except for the zoospore stage (Scott 1961, Unestam 1972), and germination outside its host is largely prevented by the specific demands for spore germination, and the ability to undergo repeated zoospore emergence when the zoospore has encysted at a location that does not promote germination. In contrast to other Aphanomyces spp., cysts of A. astaci will not germinate even in a rich nutrient medium such as PG1 (Cerenius \& Söderhäll 1985). The observed pattern of chitinase expression may thus be connected with the fact that the parasite persists in chitinous crayfish cuticle practically throughout the mycelial life stage.

\section{Chitinase is expressed in starving mycelium}

Chitinase was also produced when the mycelium was induced to sporulate. A possible explanation for upregulation upon sporulation would be that either the transcript or the protein is produced for storage in the zoospores to be used at the earliest stages of infection. This is, however, contradicted by the fact that no AaChi1 mRNA was detected in the zoospores and there are also no indications that chitinase would be stored in the zoospores or released at the time of germination, neither in our results nor in Söderhäll et al. (1978), and thus this hypothesis seems less feasible. Since increase in transcription is seen also in the non-sporulating mutant G1, it rather seems that the chitinase is expressed in hyphae that have not yet started to differentiate into sporangia. In the dying crayfish softening of the cuticle is frequently observed, possibly as a result of extensive chitinase and proteinase activities, and hyphae are penetrating the cuticle from the inside before zoospores are released in the surrounding water. It is thus possible that starvation, resulting from the washing with lakewater, will initiate both production of chitinases and sporulation. In contrast, the amounts of the transcript AaSP2, encoding a putative trypsin, rapidly decreased upon the onset of sporulation, showing that although the 2 transcripts encode enzymes suggested to be involved in infection, they are subjected to different modes of regulation. In theory the chitinases expressed upon sporulation may play a role in development, but since none of the other Aphanomyces species studied produced chitinase upon sporulation this seems most unlikely.

\section{Chitinase production is diagnostic for Aphanomyces astaci}

Different species of Aphanomyces have a very similar appearance. There is no simple diagnostic feature of $A$. astaci. As shown in this paper, production of high levels of chitinase in a chitin-free growth medium is a common feature of all 4 described genotypes of A. astaci which distinguishes them from all or most other Aphanomyces spp. Since the assay is fast and does not require any special skills, it may be of help for fast preliminary diagnostics and for obtaining pure cultures of $A$. astaci from cultures harbouring a mix of $A$. astaci and other species, by screening single zoospore isolates for chitinase production.

Acknowledgements. This work has been supported by a PhD fellowship to M.G.A. from the Swedish Council for Forestry and Agricultural Research (40.0201/99) and FORMAS (2001-40.0201) awarded to K. Söderhäll and by grants from the Swedish Environmental Protection Agency (V-164-00) and from FORMAS (22.3/2001-1777) to L.C. 


\section{LITERATURE CITED}

Altschul SF, Madden TL, Schaffer AA, Zhang JH, Zhang Z, Miller W, Lipman DJ (1997) Gapped BLAST and PSI-BLAST: a new generation of protein database search programs. Nucleic Acids Res 25:3389-3402

Bangyeekhun E, Cerenius L, Söderhäll K (2001) Molecular cloning and characterization of two serine proteinase genes from the crayfish plague fungus, Aphanomyces astaci. J Invertebr Pathol 77:206-216

Cerenius L, Söderhäll K (1985) Repeated zoospore emergence as a possible adaptation to parasitism in Aphanomyces. Exp Mycol 9:259-377

Cerenius L, Söderhäll K (1992) Crayfish diseases and crayfish as vectors for important diseases. Finn Fish Res 14: $125-133$

Clarkson JM, Charnley AK (1996) New insights into the mechanisms of fungal pathogenesis in insects. Trends Microbiol 4:197-203

Diéguez-Uribeondo J, Cerenius L (1998) The inhibition of extracellular proteinases from Aphanomyces astaci by three different proteinase inhibitors from crayfish blood. Mycol Res 102:820-824

Diéguez-Uribeondo J, Cerenius L, Söderhäll K (1994) Repeated zoospore emergence in Saprolegnia parasitica. Mycol Res 98:810-815

Diéguez-Uribeondo J, Huang TS, Cerenius L, Söderhäll K (1995) Physiological adaptation of an Aphanomyces astaci strain isolated from the warm-water crayfish Procambarus clarkii. Mycol Res 99:574-578

El-Sayed GN, Coudron TA, Ignoffo CM (1998) Chitinolytic activity and virulence associated with native and mutant isolates of an entomopathogenic fungus, Nomuraea rileyi. J Invertebr Pathol 54:394-403

Escott GM, Hearn VM, Adams DJ (1998) Inducible chitinolytic system of Aspergillus fumigatus. Microbiology 144:1575-1581

Havukkala I, Mitamura C, Hara S, Hirayae K, Nishizawa Y, Hibi $T$ (1993) Induction and purification of Bauveria bassiana chitinolytic enzymes. J Invertebr Pathol 61:97-102

Hearn VM, Escott GM, Glyn E, Evans V, Adams DJ (1998) Complex chitinolytic system of Aspergillus fumigatus. Microbios 93:85-104

Huang TS, Cerenius L, Söderhäll K (1994) Analysis of the genetic diversity in crayfish plague fungus, Aphanomyces astaci, by random amplification of polymorphic DNA assay. Aquaculture 26:1-10

Huang X, Zhang H, Zen KC, Muthukrishnan S, Kramer KJ (2000) Homology modeling of the insect catalytic domainoligosaccharide complex and the role of a putative active site tryptophan in catalysis. Insect Biochem Mol Biol 30:107-117

Marchuk D, Drumm M, Saulino A, Collins FS (1991) Construction of T-vectors, a rapid and general system for direct cloning of unmodified PCR products. Nucleic Acids Res 19:1154-1154

Nyhlén L, Unestam T (1975) Ultrastructure of the penetration of the crayfish integument by the fungal parasite Aphanomyces astaci (oomycete). J Invertebr Pathol 26:356-366

Nyhlén L, Unestam T (1980) Wound reactions and Aphanomyces astaci growth in crayfish cuticle. J Invertebr Pathol 36:187-197

Persson M, Häll L, Söderhäll K (1984) Comparison of pepti- dase activities in some fungi pathogenic to arthropods. J Invertebr Pathol 44:342-348

Sambrook J, Fritsch EF, Maniatis T (1989) Molecular cloning: a laboratory manual, 2nd edn. Cold Spring Harbor Laboratory Press, New York

Samuels KDZ, Heale JB, Llewellyn M (1989) Characteristics relating to the pathogenicity of Metarhizium anisopliae toward Nilaparvata lugens. J Invertebr Pathol 53:25-31

Schickler H, Haran S, Oppenheim A, Chet I (1998) Induction of the Trichoderma harzianum chitinolytic system is triggered by the chitin monomer, $\mathrm{N}$-acetylglucosamine. Mycol Res 102:1224-1226

Scott WW (1961) A monograph of the genus Aphanomyces. VA Agric Res Station Tech Bull 151:1-95

Shakarian AM, Dwyer DM (1998) The LdCht1gene encodes the secretory chitinase of the human pathogen Leishmania donovani. Gene 208:315-322

Söderhäll K, Unestam T (1975) Properties of extracellular enzymes from Aphanomyces astaci and their relevance in the penetration process of crayfish cuticle. Physiol Plant 35:140-146

Söderhäll K, Svensson E, Unestam T (1978) Chitinase and protease activities in germinating zoospore cysts of the parasitic fungus, Aphanomyces astaci, Oomycetes. Mycopathologia 64:9-11

St Leger RJ, Cooper RM, Charnley AK (1991) Characterization of chitinase and chitobiase produced by the entomopathogenic fungus Metarhizium anisopilae. J Invertebr Pathol 58:415-426

St Leger RJ, Staples RC, Roberts D (1993) Entomopathogenic isolates of Metarhizium anisopliae, Beauveria bassiana, and Aspergillus flavus produce multiple extracellular chitinase isozymes. J Invertebr Pathol 61:81-84

St Leger RJ, Cooper RM, Charnley AK (1996a) Cuticle degrading enzymes of entomopathogenic fungi: regulation of the production of chitinolytic enzymes. J Gen Microbiol 132:1509-1517

St Leger RJ, Joshi L, Bidochka MJ, Rizzo NW, Roberts DW (1996b) Characterization and ultrastructural localization of chitinases from Metarhizium anisopliae, M. flavoviride, and Beauveria bassiana during fungal invasion of host (Manduca sexta) cuticle. Appl Environ Microbiol 62: 907-912

Thompson JD, Higgins DG, Gibson TJ (1994) CLUSTAL W: improving the sensitivity of progressive multiple sequence alignment through sequence weighting, position specific gap penalties and weight matrix choice. Nucleic Acids Res 22:4673-4680

Tronsmo A, Harman GE (1993) Detection and quantification of $\mathrm{N}$-acetyl-beta-D-glucosaminidase, chitobiosidase, and endochitinase in solutions and on gels. Anal Biochem 208:74-79

Unestam T (1965) Studies on the crayfish plague fungus, Aphanomyces astaci. I. Some factors affecting growth in vitro. Physiol Plant 18:483-505

Unestam T (1966) Chitinolytic, cellulolytic and pectinolytic activity in vitro of some parasitic and saprophytic oomycetes. Physiol Plant 19:15-30

Unestam T (1972) On the host range and origin of the crayfish plague fungus. Rep Inst Freshwat Res (Drottningholm) 49:192-198

Vilcinscas A, Götz P (1999) Entomopathogenic fungi and the insect immune system. In: Baker JR, Muller R, Rollinson D (eds) Advanced Parasitology, Vol 43. Academic Press, London, p $273-274$ 